\title{
THE VERACRUZ EARTHQUAKE OF 28 AUGUST 1973
}

\author{
H. M. Irvine*
}

\section{FOREWORD}

The author was on holiday in Mexico City at the time of the earthquake, and felt his hotel building sway. He concluded that the ground shaking near the center of the earthquake must have been of destructive intensity and, therefore, it would be worthwhile to investigate the damage. Professor Emilio Rosenblueth of the Instituto de Ingenieria of the University of Mexico (UNAM) arranged for the author to join the team of engineers from the Instituto for their visit to the damaged area on the 29th, 30th and 3lst of August. Initially, the group consisted of Professors Enrique del Valle and Oscar Hernandez, Ing. Roberto Villaverde, and the author. Later, on 30 August, this group was joined by Ing. Alejandro Gonzales, Ing. Belzay Romero, Ing. José Suarez and Mr. John F. Meehan, Research Director of the Office of Architecture and Construction, State of California. To these people the author expresses his sincere thanks for their consideration, and for the interesting discussions of the damage.

\section{INTRODUCTION}

The earthquake, which caused widespread damage in parts of the states of Puebla and Veracruz in southeast Mexico, registered 7.0 on the Richter Magnitude scale, according to the Caltech Seismological Laboratory. The earthquake occurred at $3: 51$ (local time) on the morning of 28 August 1973. The center of destructive shaking was in the vicinity of serdän in the state of Puebla (19N97W) (see Figure 1).

The National Earthquake Information Service reports the earthquake as occurring at $09: 50: 41.6 \mathrm{GMT}$ with the instrumental epicenter at $18.275 \mathrm{~N} 96.584 \mathrm{~W}$, and the hypocenter at a depth of approximately $100 \mathrm{~km}$. The most seismic region of Mexico is along the southwest coast. Earthquakes in the region of Orizaba have been relatively infrequent; the most recent serious ground shaking occurred June 17, 1928 when a magnitude 7.8 shock had its epicenter at $16 \mathrm{~N} 98 \mathrm{~W}$, some $250 \mathrm{~km}$ south of Serdán.

The damaged area in the state of Veracruz is in a tropical, mountainous region. Dense rainforest covers the slopes; coffee and sugar cane are farmed extensively. Figure 2 shows a typical view of the countryside, with the highest mountain in Mexico, Orizaba Peak $\left(5,700 \mathrm{~m}_{\circ}\right)$, in the background. The earthquake occurred during the rainy season, and this naturally hampered rescue work. Serdán, in the state

\footnotetext{
* Lecturer in Civil Engineering, University
} of Auckland. of Puebla, has a much dryer climate, as it is in the rainshadow on the other side of the mountains. The main crop there is corn.

Many persons lost their lives during the earthquake; the death toll has been tentatively placed at 500, with perhaps three times as many injured. Many thousands were made homeless. Severe damage to property was confined to a region of approximately $30 \mathrm{~km}$ radius around Serdán. Worst hit were the Cities of Serdán (12,000 pop.) in the State of Puebla, Orizaba (110,000 pop.), Córdoba (110,000 pop.), and Rio Blanco $(27,000$ pop.) in the state of Veracruz. Villages in the mountains or nearby are also reported to have been badly hit. The disastrous consequences of the earthquake were accentuated by the very heavy rains that preceded and followed the earthquake.

The shaking was distinctly felt in Mexico City some $200 \mathrm{~km}$. northwest of Serdán. There, the duration of the shaking was of the order of one to two minutes, and the multistorey buildings in downtown Mexico City swayed appreciably. There were no reports of any structural damage in Mexico City.

It was apparent from investigations of the damage in the central region of the earthquake that the intensity of ground shaking was not exceptionally severe. The numerous obelisks and statues in the towns visited were not toppled. Also, soil failures (apart from a few rock and mudslides in the mountains between Puebla and Rio Blanco) and hydrologic damage appeared minimal - the author saw only one broken watermain. Some machinery in the textile factory in Rio Blanco appeared to have moved about $1 \mathrm{~cm}$. on its bearing pads. All this, together with the estimate of $100 \mathrm{~km}$. for the hypocenter, suggests less intense ground shaking than would normally be expected in the central region of a magnitude 7.0 earthquake. Consequently, much of the structural damage did not result from strong ground shaking, but rather from inadequate design procedures and low standards of construction. The latter is particularly true of housing. At present, only Mexico City and Acapulco have earthquake design codes, and the Cordoba-orizaba region did not have any code requirements for earthquake design.

\section{Rio Blanco}

The textile town of Rio Blanco $(27,000$ pop.) near orizaba, was one of the first visited. The town lies in a small alluvial valley, and is ringed by mountains. Damage was extensive in the residential areas. Generally, the houses had walls of stone masonry or brick masonry with rather weak 
mortar. The roofs were either corrugated iron or tile. Figure 3 shows typical damage to housing.

The damage was most severe in the area nearest the hills. Possible geologic reasons that might be advanced for this are: reflection of incident waves, (b) poor soil conditions (possibly). However, from discussions with residents, it appears that the houses in the most severely damaged areas were older, and, therefore, not as earthquake resistant. Also, as fate would have it, a troublesome gas main in this location had recently been removed by blasting it out of the ground. This could well have put a maze of hairline cracks in many of the buildings.

The textile factory, on which the livelihood of the town depends, suffered little structural damage. The structural frame of the factory consisted of steel columns and steel roof trusses. The exterior walls were brick filler walls. There appeared to be no damage to spinning machines, or to the electrical switching gear. The administrative offices of the factory (of brick and mortar construction) suffered extensive damage.

\section{Orizaba}

There was quite extensive damage to a variety of buildings in Orizaba $(110,000$ pop.). Many houses collapsed but, since these failures were, in general, similar to those mentioned earlier, they will be passed over in order to concentrate on descriptions of larger, more modern buildings which often fared badly in the earthquake. Figure 4 shows a general view of orizaba taken before the earthquake.

A. Social Security Hospital. - The Social Security Hospital is a modern, sevenstorey structure built in 1958. The building is divided into three parts by construction joints on either side of the elevator shafts and access stairways. The main frame consists of reinforced concrete columns and floor slabs, with unreinforced brick and mortar filler walls (see Figure 5). The hospital suffered major secondary damage. In fact, the secondary damage was so severe that the top five floors were unusable. On each of these floors there was a terrific mess of broken wall tiles, reagents, hospital equipment and fractured secondary walls which, although unreinforced, had not been isolated from the main frame. Fortunately, the rest of the hospital was operational, although the staff were sorely pressed at a time when every inch of the hospital was urgently needed. The main frame of the hospital suffered little damage. The floor slabs had cracked on some floors and some of the columns had spalled. Figure 6 shows evidence of some working of the construction joints. However, plumb-Iine checks revealed that no permanent lateral displacement had taken place.

The boiler house is located adjacent to, but isolated from, the right-hand end of the main building. This building has a single-storey, single-bay, reinforced concrete frame supporting a reinforced concrete floor slab. During the earthquake, plastic hinges formed in three of the four joints. Had the shaking been more intense it is clear that this building would probably have collapsed and the danger of serious explosions would have been extreme, since the boilers are fed from exposed propane tanks nearby.

B. The "Packard" Apartment Building. - The complex consisted of three, threestorey buildings linked by terraces and stairways. Two of the buildings collapsed killing ten people, injuring 40 and crushing 20 cars parked underneath on the ground floor (see Figures 7 and 8 ). The end of the building, still standing, was markedly stiffer than the other part which appeared to have been supported on slender columns. Notice also, the flexural-shear failure of the short columns which provided the ventilation gap for the ground floor shops (see Figure 9). The whole complex was torsionally unbalanced because of the linking terraces and stairways which provided shear transfer between adjacent buildings.

C. Technologico of Orizaba. - This modern complex of school buildings is si.tuated on the outskirts of orizaba and provides tertiary technical education and training for the area. Two four-storey classroom blocks had been extensively damaged. The buildings had reinforced concrete frames and floor slabs, and brick filler walls. Other single-storey buildings on the site had suffered little damage.

The first four-storey building (Building A) shown here consisted of two parts linked by stairways. Half of the structure collapsed completely (see Figure 10). Along the shorter sides adequate stiffness had been provided by four brick and mortar shear walls, but the building was weak along its major direction. Indeed, the rectangular columns were oriented so that their weak direction was parallel to the longer side; in plan, the column depth was approximately twice the width. Flexural-shear failure of the ground floor columns precipitated the collapse (see Figure 11). Figure 12 shows the behaviour of post-tensioned floor slabs. The hollow cardboard cylinders had been placed in the floor to save weight, but they were instrumental in the slabs losing any continuity which the prestressing cables might have provided. It is most fortunate that the earthquake occurred before school had started for the day.

The other four-storey building

(Building B) remained standing, although it is likely that it will have to be completely rebuilt (see Figure 13). Superficially, this building appeared to be similar to Building $A_{i}$ it was of the same height and plan area and stairways separated the building into two parts. However. closer examination revealed major structural differences. The center of mass of the building was towards the left-hand end, while the center of stiffness was nearer the stairway (see Figures 13 and 14). Hence, the building responded primarily in torsion. Good evidence of this is provided by Figure 15 which shows classical torsional cracking of a second-storey column located adjacent to the stairway. 


\section{Córdoba}

Córdoba is a city of much the same size as Orizaba. Here, also, there was extensive damage in residential and commercial areas.

A. Five-Storey Business House. - The failure of this building was one of the most interesting, from an engineering standpoint. This building, which had a reinforced concrete frame with brick filler walls, is owned by Mr. Kushida, a Japanese businessman, and was built in 1968. The bottom three floors house shops, offices and warehouses, whereas the top two floors, which are set back (see Figure 16), are occupied by Mr. Kushida and his family. The overturning moment resulting from the motion of the top two floors caused axial compression failures of columns of the third floor (see Figure 17). The upper floors had dropped approximately $30 \mathrm{~cm}$. and were severely damaged. Goods stored in this building were subsequently damaged by heavy rainfall.

B. Hotels. - The Hotel Trueba (see Figure 18), which has a reinforced concrete frame with brick filler walls, suffered extensive secondary damage, mainly to unreinforced brick and mortar partition walls which had been made continuous with the structural frame. The six-storey shear walls showed evidence of cracking at the second and third floors (see Figure 19). This could indicate some second-mode response to the excitation. However, this seems unlikely since the participation factor for second-mode response is usually too small to be significant. The building is more likely to have responded strongly in the first mode, in which case local weaknesses in the construction at the second and third floors could have led to the cracking which occurred there. Another possibility is that the wall behaved as a coupled shear wall (the coupling between the two columns being provided by the floors and the infill walls) where, typically, laminar shear stresses attain their maximum values about one-third of the way up the shear wall.

For whatever reason, the behaviour of the wall is peculiar since Figure 18 shows an obvious zone of weakness at the level of the ground floor columns. Yet inspection showed no sign of damage to these columns. It can only be concluded that sufficient stiffness was present in the ground floor to avoid damage there.

Since many of the rooms in the hotel were uninhabitable owing to broken partition walls, the owner was very keen to have repairs made as soon as possible. Unfortunately, the philosophy behind the repair scheme left much to be desired, as Figure 20 shows.

Another modern six-storey building, the Hotel Palacio, was better constructed and damage was minor. Some interior walls had diagonal-tension cracks between adjacent doorways.

The Hotel Zevallos is one of the oldest buildings in Córdoba, having been built in 1687, just 70 years after the Spaniards founded the town. Although the exterior of the building has changed somewhat (see Figure 21) and a reinforced concrete roof was placed earlier this century, the interior courtyard is substantially unaltered. The view of the all-but-failed three-way arch (see Figure 22) is taken from this courtyard. It appears that the roof slab saved the outer corner of the building from collapsing.

C. Service Station Shelter. - The cantilevered service station shelter shown in Figures 23 and 24 had cracked at the junction of column and roof slab, but there was no damage at the base of the column. It appears that the rotary inertia associated with the roof had been ignored in the design. The rotary inertia had two effects: firstly, under horizontal excitation the true bending moment diagram is trapezoidal, not triangular; secondly, the rotary inertia may so lower the fundamental frequency that an earthquake may cause strong excitation of what, at first, appears to be a relatively stiff single-storey structure. Punching shear may have contributed to the behaviour of the shelter, although the cracking did not extend to the other side of the column junction.

\section{Serdán}

The City of Serdán (12,000 pop.) was the last visited. It was clearly the worst hit by the disaster, with perhaps 300 deaths and many of the homes were damaged or destroyed. Serdan is a very poor agricultural town, and the houses consisted of walls of stone and clay mortar and tile roofs. Figure 25 shows typical damage to such buildings. It appears that the town is too poor to finance an adequate rehousing project, and the Federal Government will have to assume responsibility for the rebuilding. In the meantime, some of the houses, which were only partially damaged, will be rebuilt using the age-old methods. Consequently, the next strong earthquake will again wreak havoc in the town. The pattern is, unfortunately, all too familiar in the country areas of Latin America.

By and large, the more modern buildings in Serdán fared better. An exception was the new trade school where there was considerable damage to unreinforced brick and mortar filler walls. There was also evidence of damage to the main frame of the building.

\section{CONCLUSIONS}

The region most heavily shaken by the earthquake is one of the less affluent parts of the country, and because of this the quality of construction was, in general, not good. There were no earthquake requirements in the building code and, in fact, it appeared that no building code was enforced. This contrasts markedly with the quality of new construction in Mexico City and Acapulco where there are earthquake requirements in the building code. Even though the Córdoba-Orizaba region is relatively poor, it appears that even a moderate enforcement of earthquake requirements would 
have greatly improved the earthquake resistance of many of the buildings at little, if any, extra cost. A destructive earthquake usually is required to initiate action, and it will be interesting to observe whether the earthquake of 28 August 1973 will cause Córdoba and orizaba to improve the earthquake-resistant design of major structures.

Another point concerns secondary damage which is often overlooked, even in areas of the world where adequate earthquake codes are in use. Interior walls, which have no load bearing function, and equipment stored and used in buildings must receive special consideration. By paying a little extra attention to such details the community can be saved a great deal of cost and inconvenience.

One lesson to be learned from the veracruz earthquake is that a location on the border of a highly seismic region, as was the Córdoba-orizaba area, that had experienced little destructive shaking in the recent past, can yet be shaken strongly enough to cause a disaster.

The hypocenter of the 28 August 1973 shock was relatively deep, approximately $100 \mathrm{~km}$. Such depths seem to be usual for earthquakes in this general area of Mexico and, as a consequence, the intensity of ground shaking in the central region is not as intense as it would be if the hypocenter were at a depth of $10 \mathrm{~km}$., which is common for California earthquakes.

This earthquake demonstrated again the serious problem posed to developing countries by destructive earthquakes. This portion of Mexico is typical of parts of many developing countries where the lack of capital and low per capita income leads to the use of the cheapest possible construction, particularly for housing. The influence of these low standards of housing seem to affect even the design of more modern engineered structures. The community is, in general, not aware of the possibility of building in such a way as to eliminate earthquake disaster, and even in those cases where sufficient money is available to design an earthquake-resistant structure, there seems to be no incentive to do so. It appears very difficult for a local government to raise the standards of building construction; the improvement of building construction is probably best done through positive action by the state Government or by the Federal Government.

\section{ACKNOWLEDGMENT}

The author wishes to express his appreciation of the assistance given by Professor G. W. Housner of the California Institute of Technology in preparing this paper.

\section{REEERENCE}

A more detailed description of the earthquake may be found in the following report, written while the author was a Graduate Research Assistant at the California Institute of Technology: quake of 28 August 1973," Report No.EERL 73-06, California Institute of Technology, Earthquake Engineering Research Laboratory, October, 1973.

Irvine, H. M., "The Veracruz Earth- 

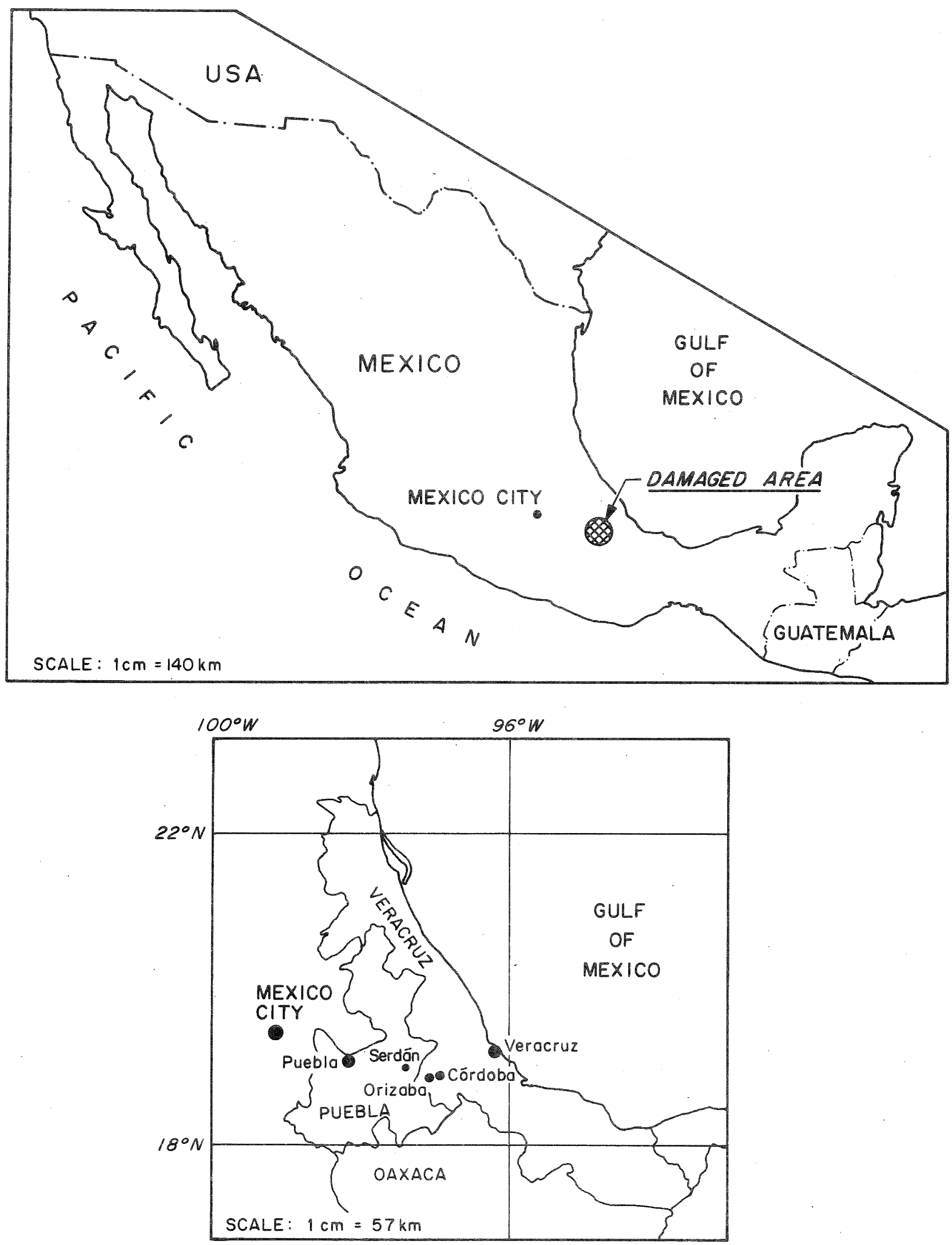

FIGURE 1: LOCATION OF DAMAGED AREA 


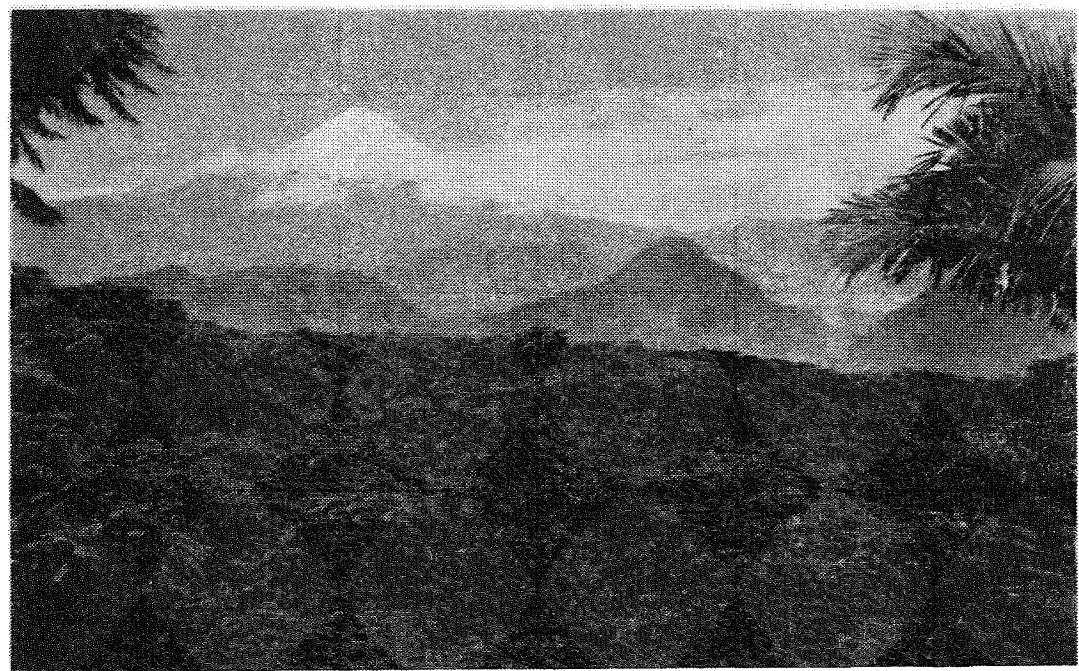

FIGURE 2: VIEW OF COUNTRYSIDE IN DAMAGED PART OF THE STATE OF VERACRUZ. MEXICO'S HIGHEST MOUNTAIN, ORIZABA PEAK $(5,700 \mathrm{~m})$ IS IN THE BACKGROUND.

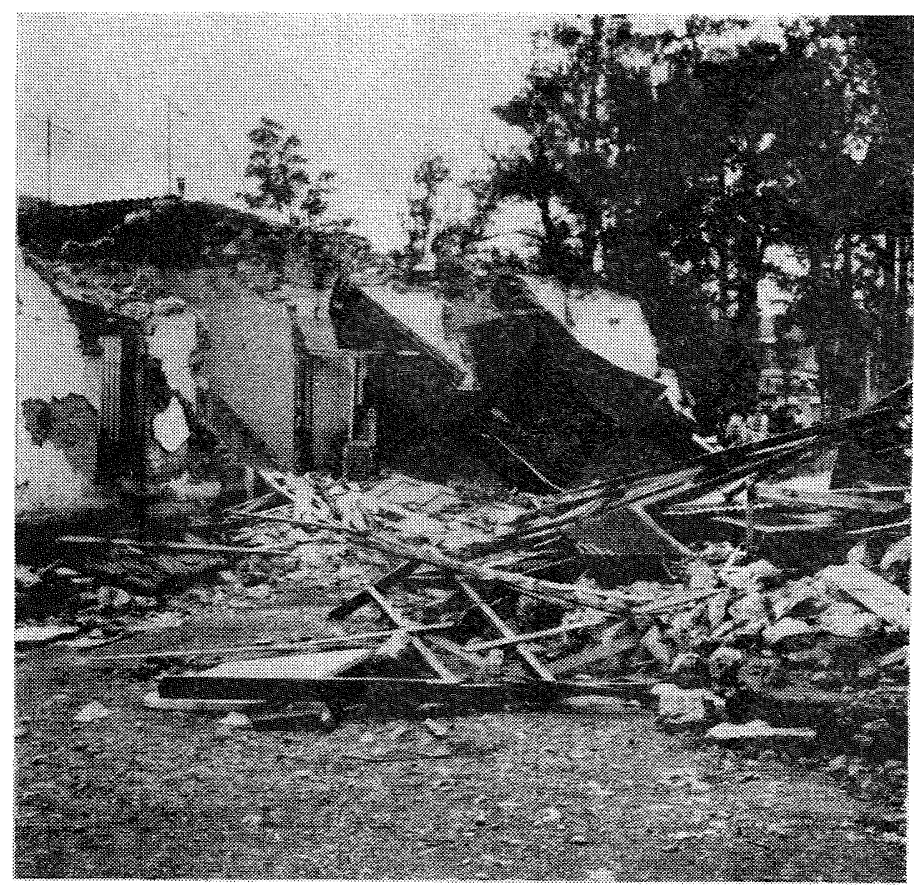

FIGURE 3: COLLAPSED HOUSES, RIO BLANCO. 


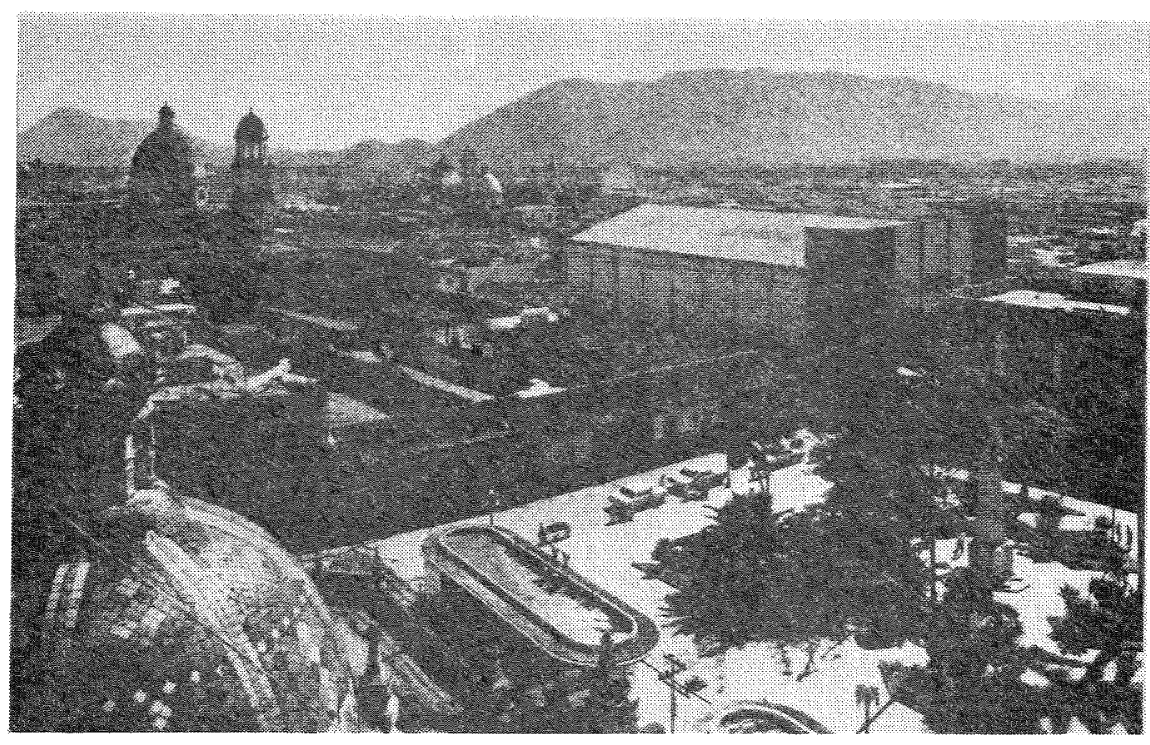

FIGURE 4: VIEW OF ORIZABA TAKEN BEFORE THE EARTHQUAKE.

NUMEROUS OLD CHURCHES IN THE AREA WERE BADLY HIT

BY THE EARTHQUAKE.

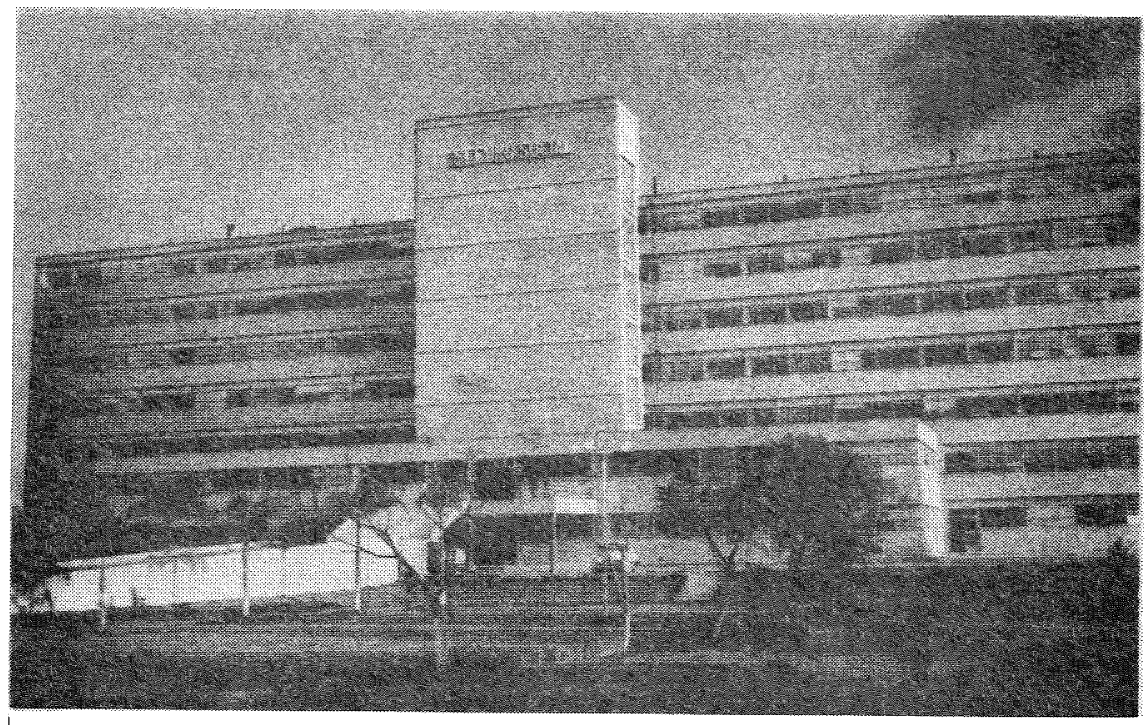

FIGURE 5: SOCIAL SECURITY HOSPITAL, ORIZABA 


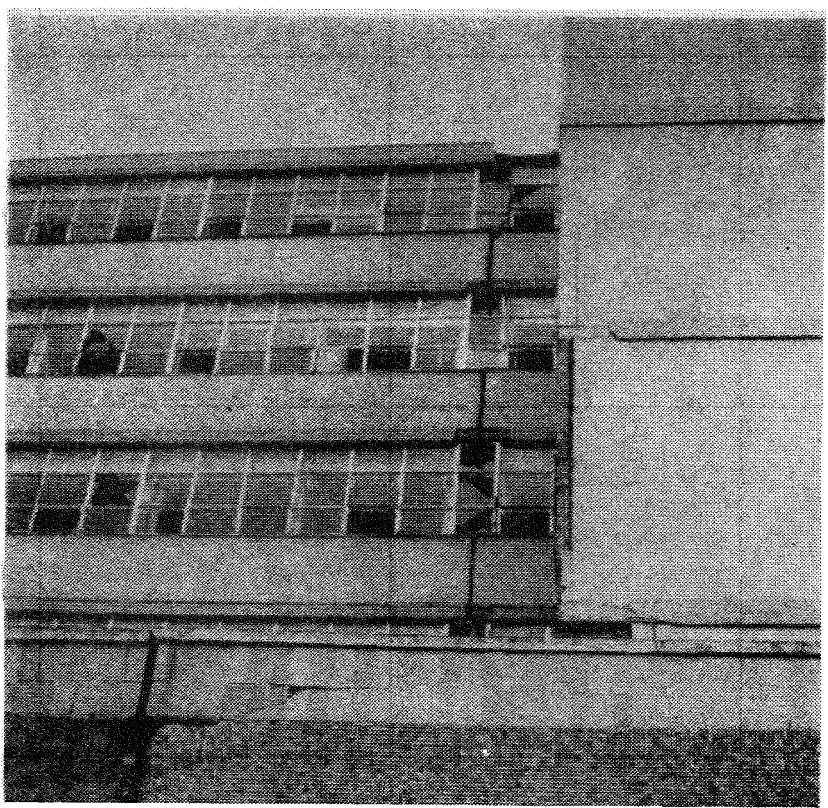

FIGURE 6: WORKING OF A CONSTRUCTION JOINT SOCIAL SECURITY HOSPITAL.

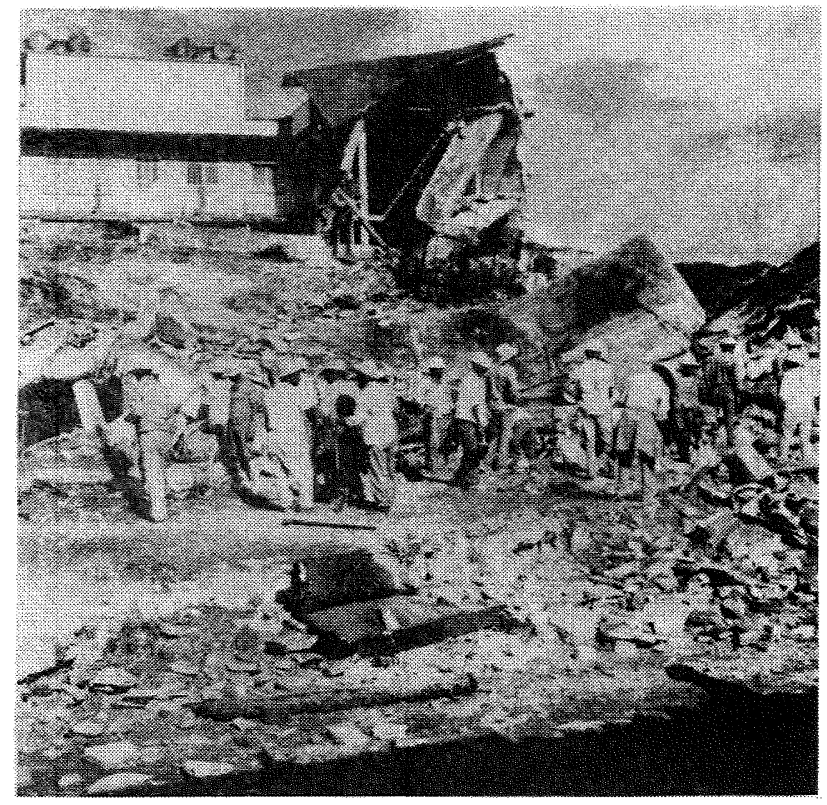

FIGURE 8: THE "PACKARD" APARTMENT BUILDING. WORKMEN ARE STANDING ON WHAT WAS THE REINFORCED CONCRETE ROOF OF THE THREESTOREY COMPLEX.

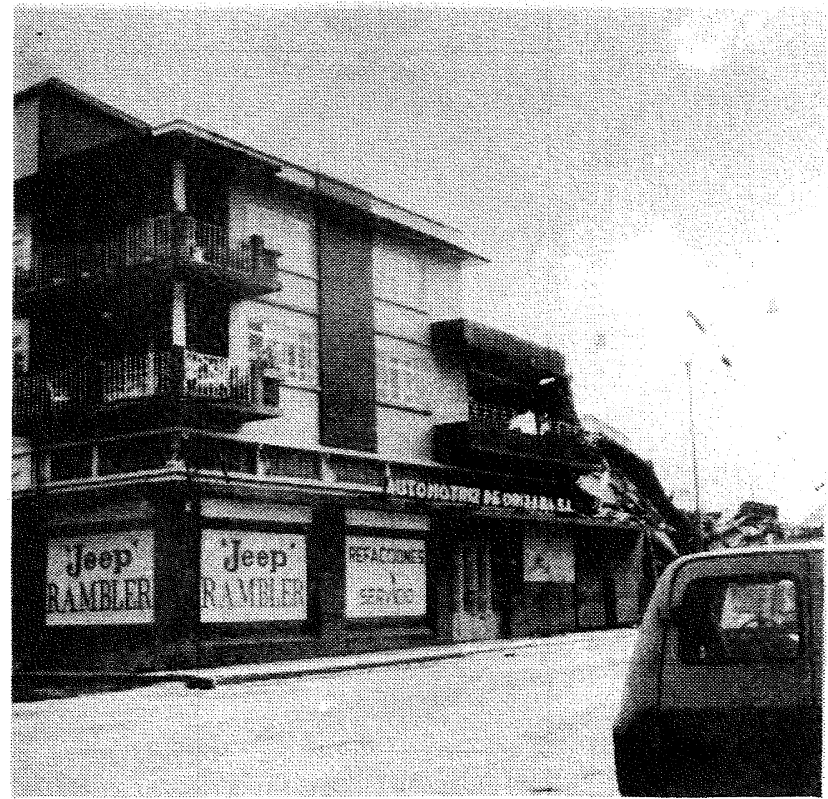

FIGURE 7: COLLAPSE OF THE "PACKARD" APARTMENT BUILDING, ORIZABA.

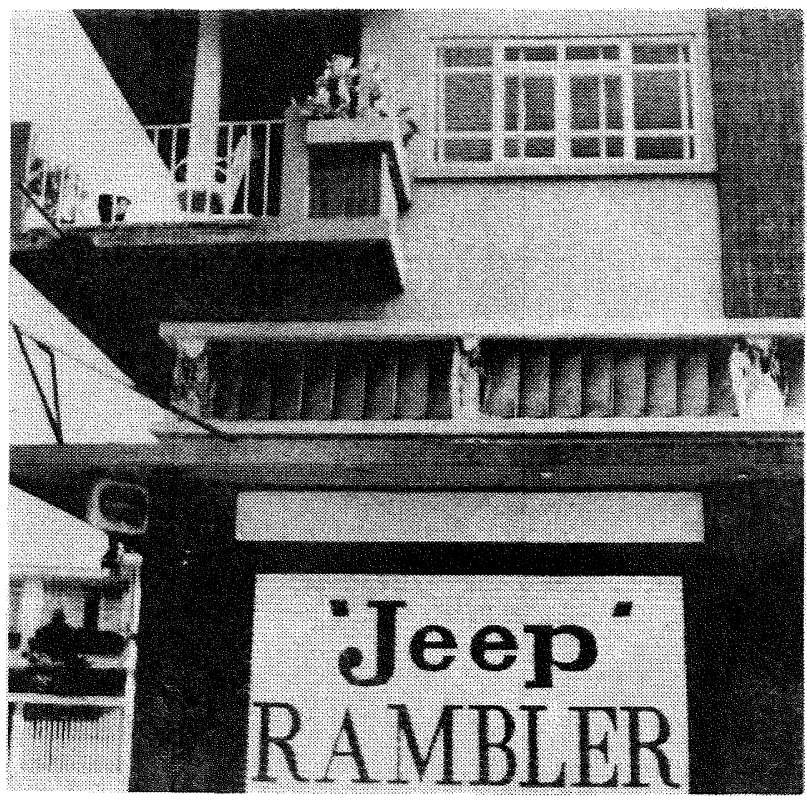

FIGURE 9: FAILURE OF SHORT COLUMNS,

"PACKARD" APARTMENT BUILDING. 


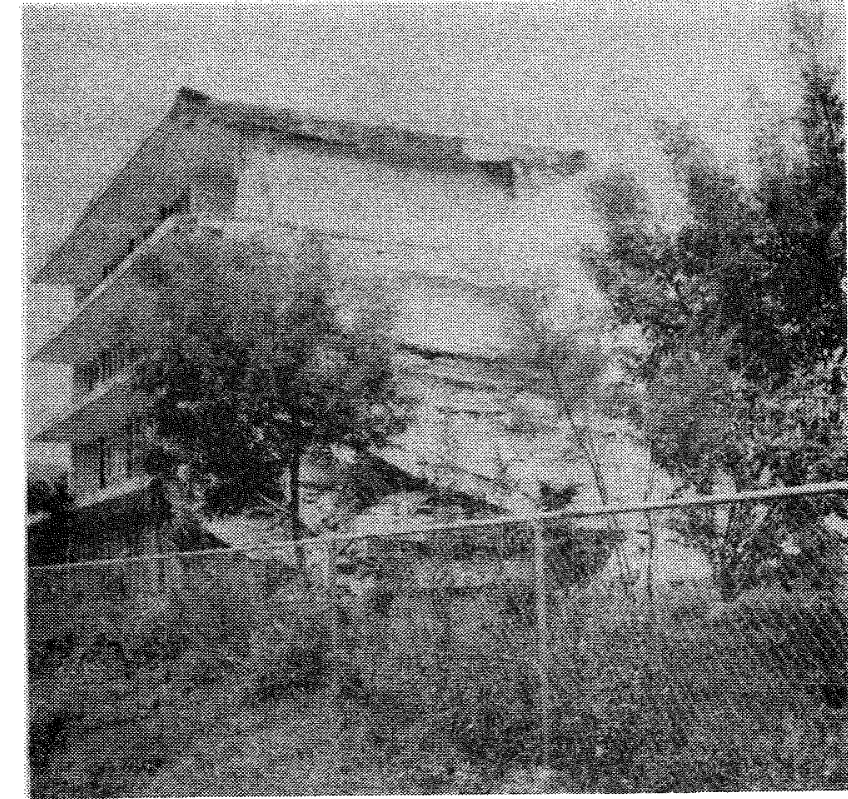

FIGURE 10: COLLAPSE OF BUILDING $A$, TECHNOLOGICO OF ORIZABA.

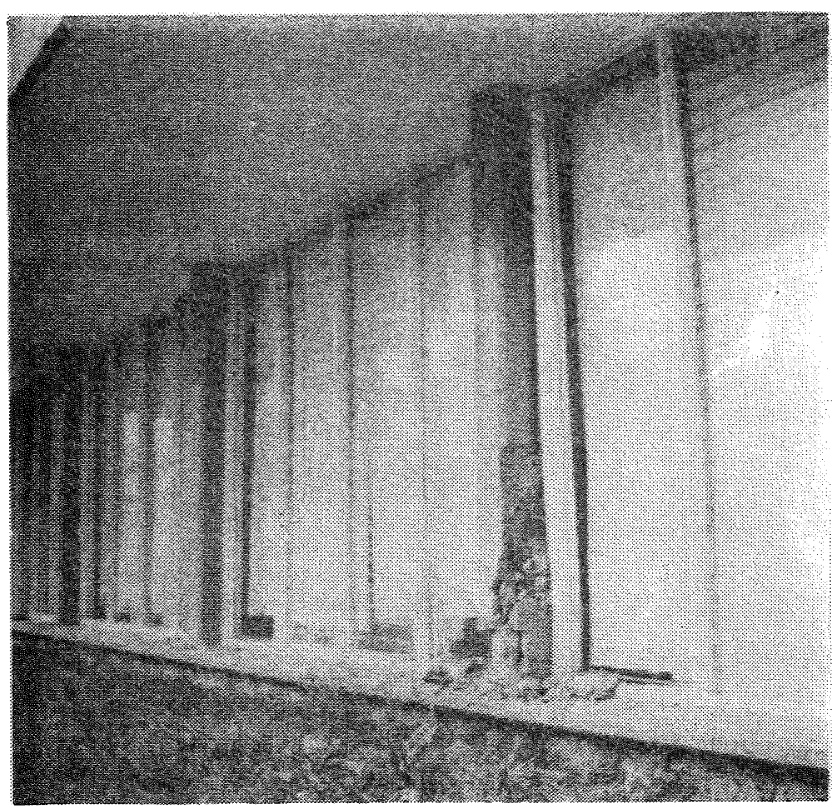

FIGURE 11: FAILURE OF GROUND-FLOOR COLUMNS, BUILDING A, TECHNOLOGICO OF OAIZABA.

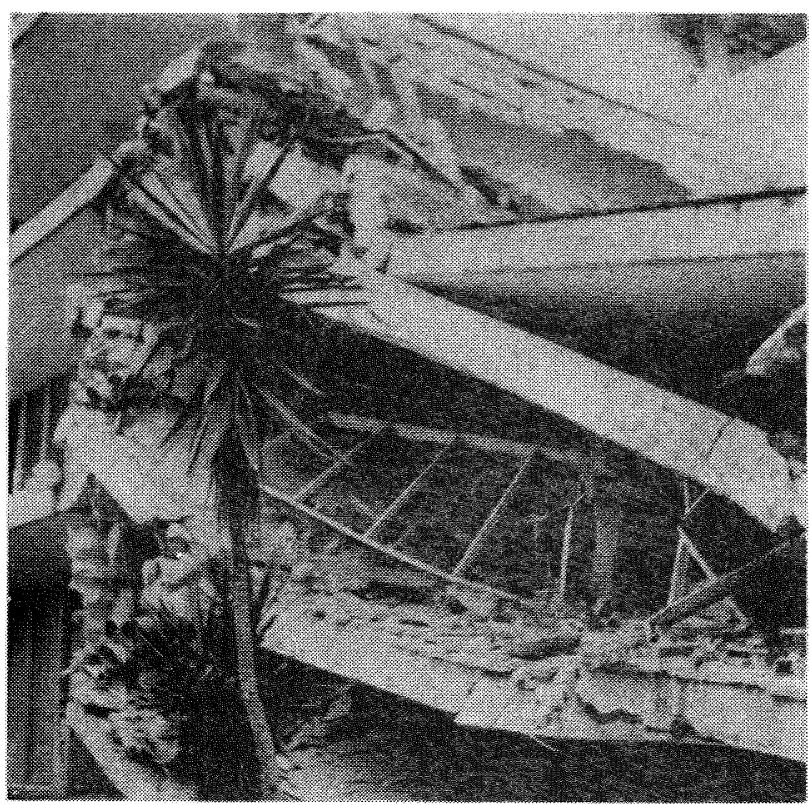

FIGURE 12: BEHAVIOUR OF FLOOR SLABS, BUILDING A, TECHNOLOGICO OF ORIZABA.

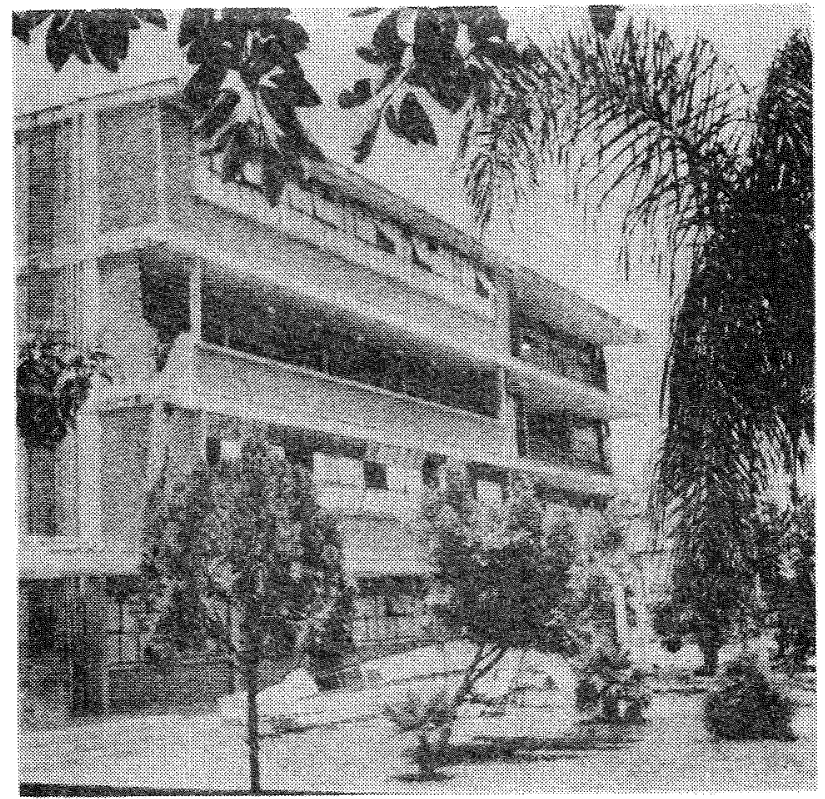

FIGURE 13: DAMAGE TO BUILDING B, TECHNOLOGICO OF ORIZABA. 


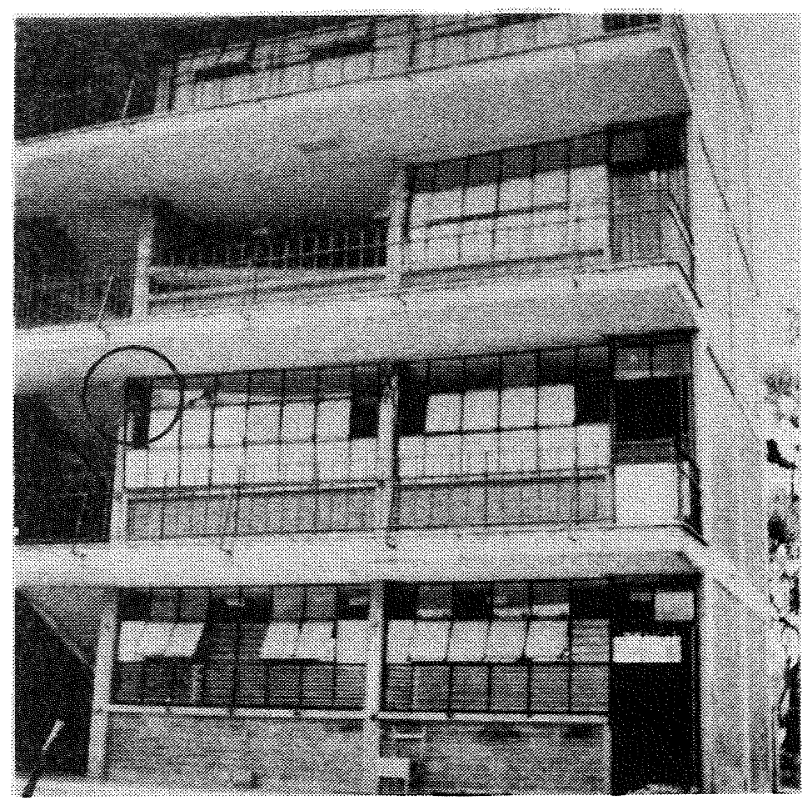

FIGURE 14: BUILDING B, TECHNOLOGICO OF ORIZABA. CIRCLE GIVES LOCATION OF FIGURE 15.

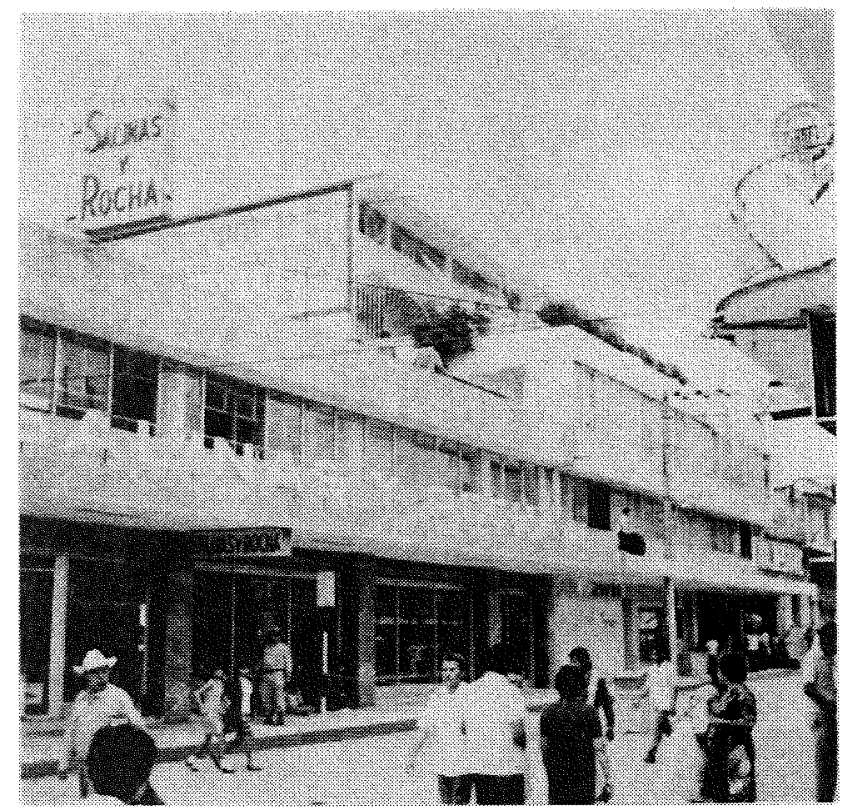

FIGURE 16: FIVE-STOREY BUSINESS HOUSE, CORDOBA.

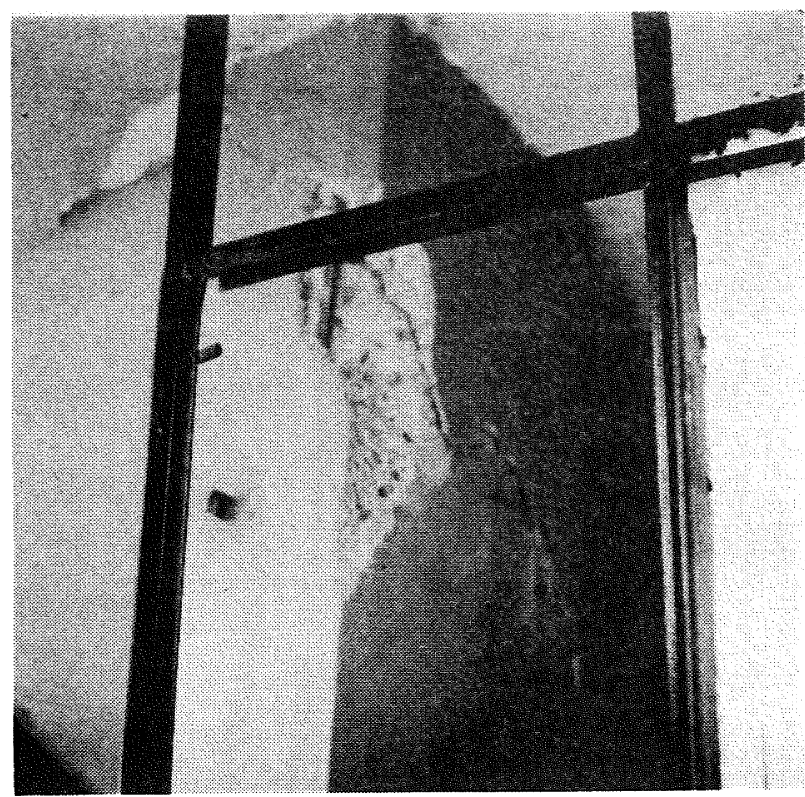

FIGURE 15: TORSIONAL CRACKING OF SECOND-STOREY COLUMN, BUILDING B, TECHNOLOGICO OF ORIZABA.

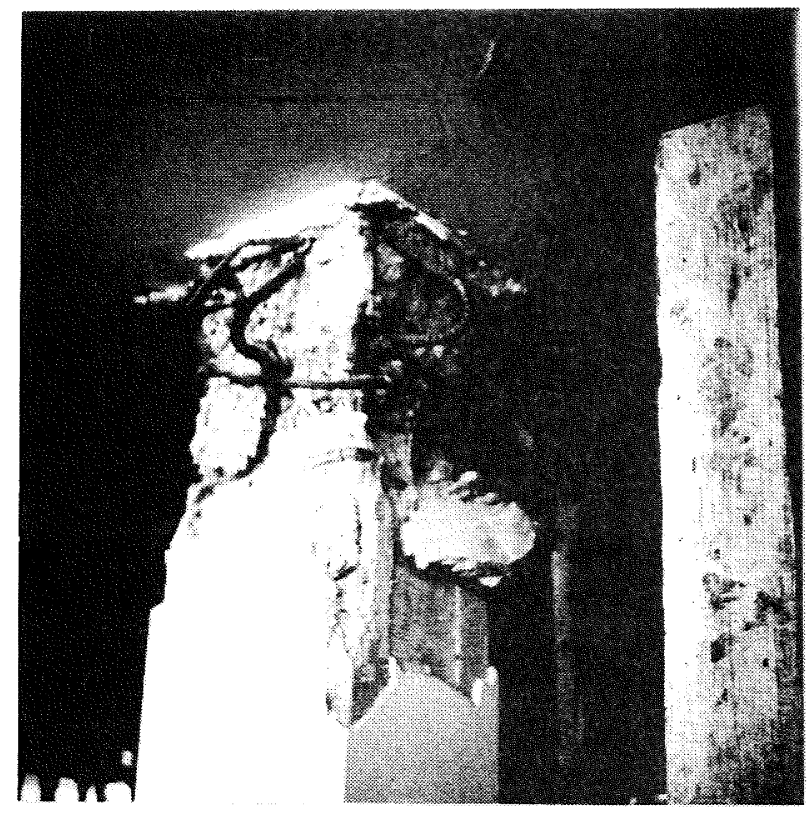

FIGURE 17: AXIAL COMPRESSION FAILURE OF A THIRD-FLOOR COLUMN, BUSINESS HOUSE, CORDOBA. 


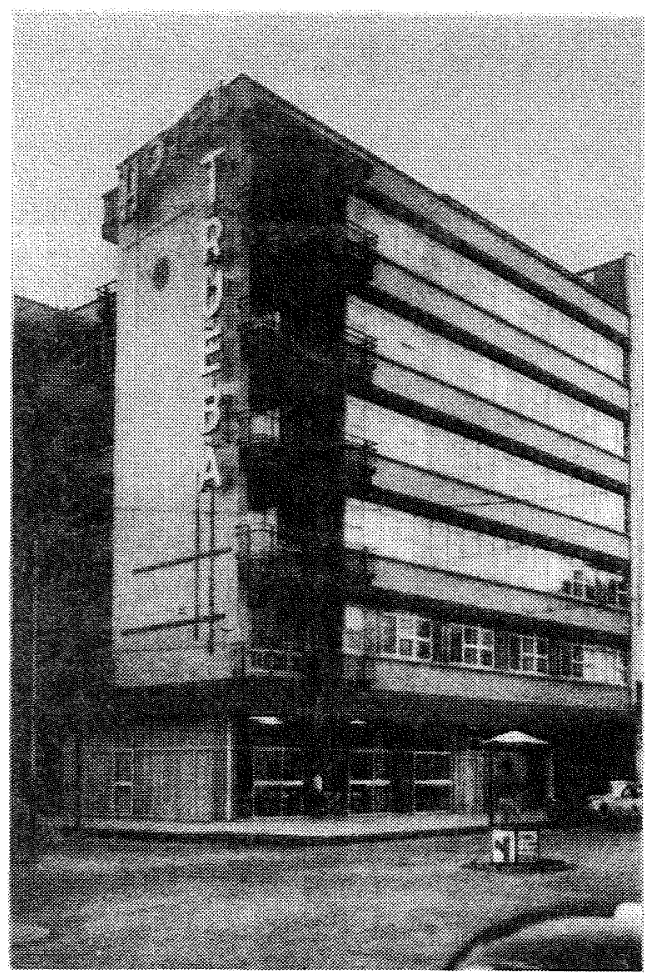

FIGURE 18: HOTEL TRUEBA, CORDOBA, BEFORE THE EARTHQUAKE.

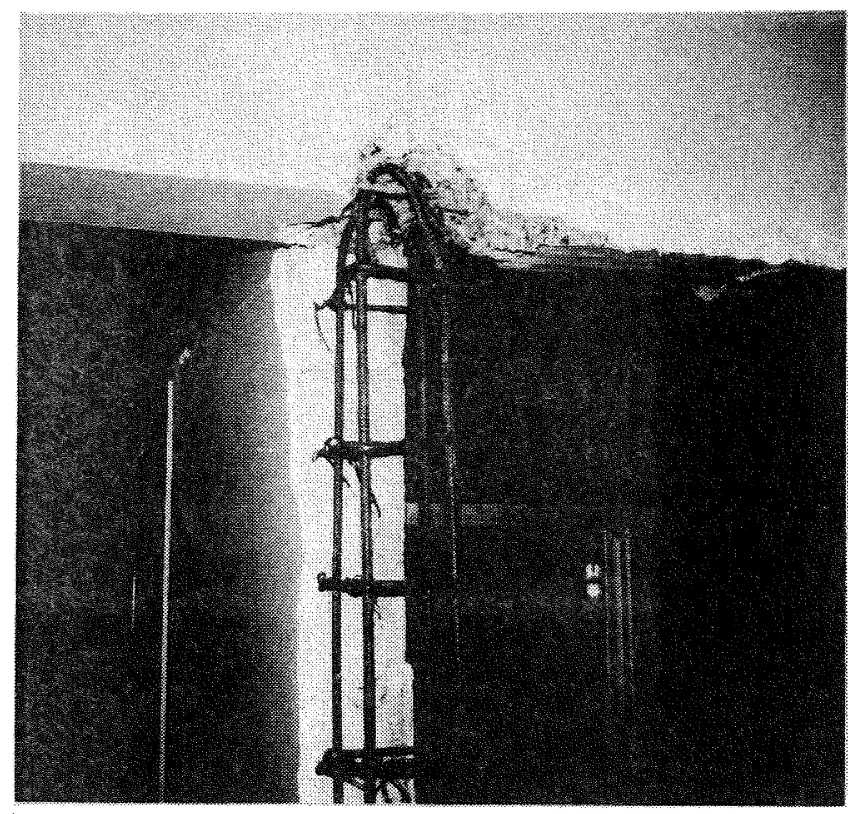

FIGURE 20: REPAIR SCHEME FOR PARTITION WALL; HOTEL TRUEBA.

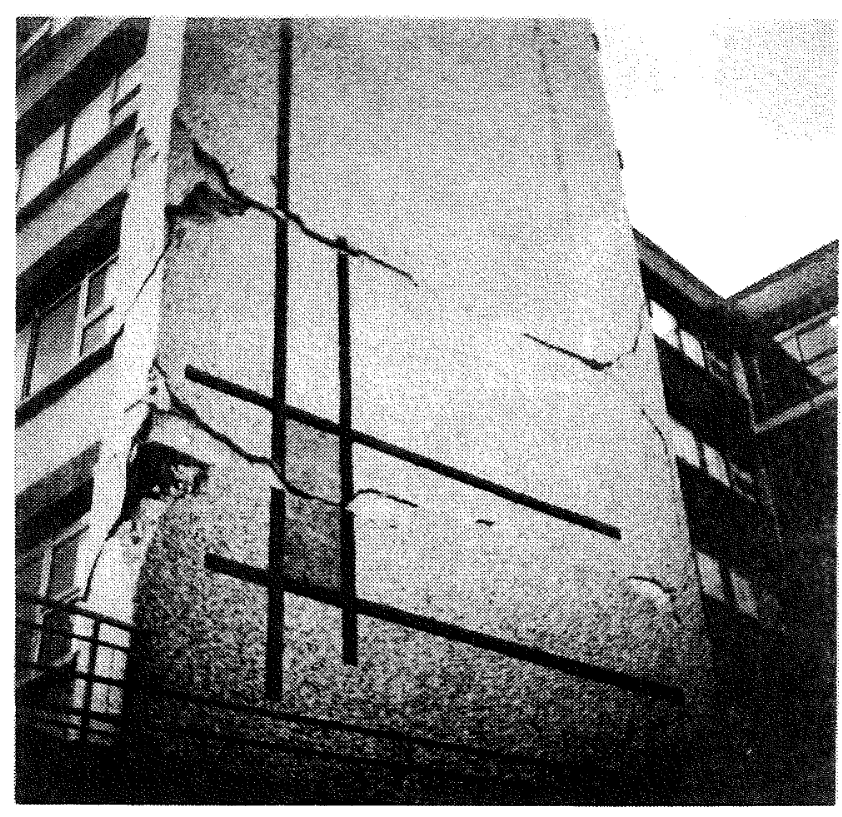

FIGURE 19: CRACKING IN SHEAR WALL, HOTEL TRUEBA.

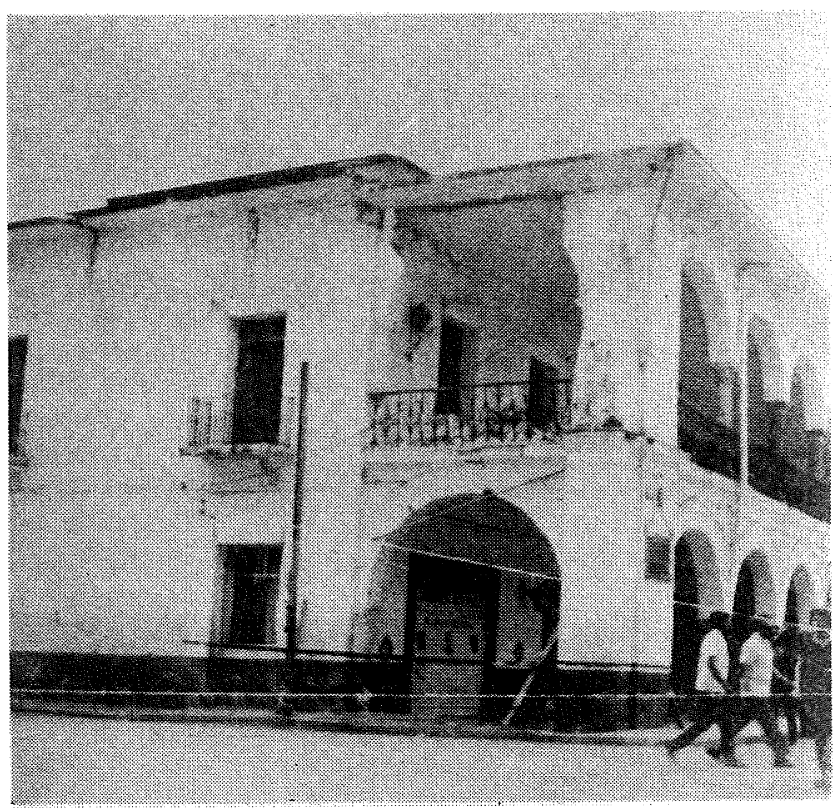

FIGURE 21: DAMAGE TO EXTERIOR CORNER OF THE HOTEL ZEVALLOS, CORDOBA. 


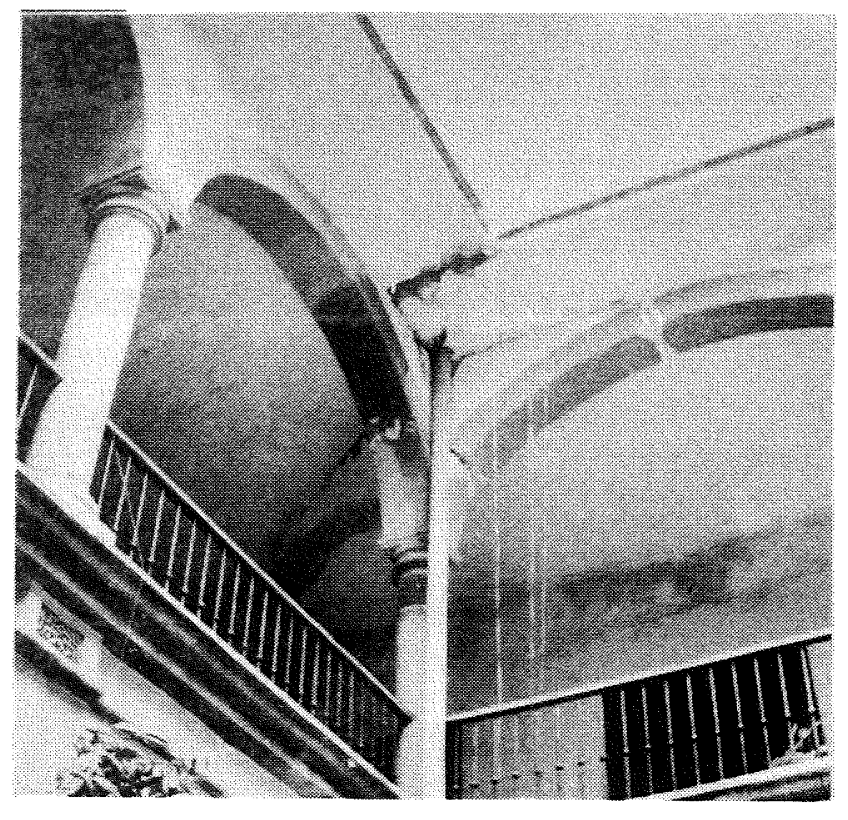

FIGURE 22: DAMAGE TO THREE-WAY ARCH, HOTEL ZEVALLOS.

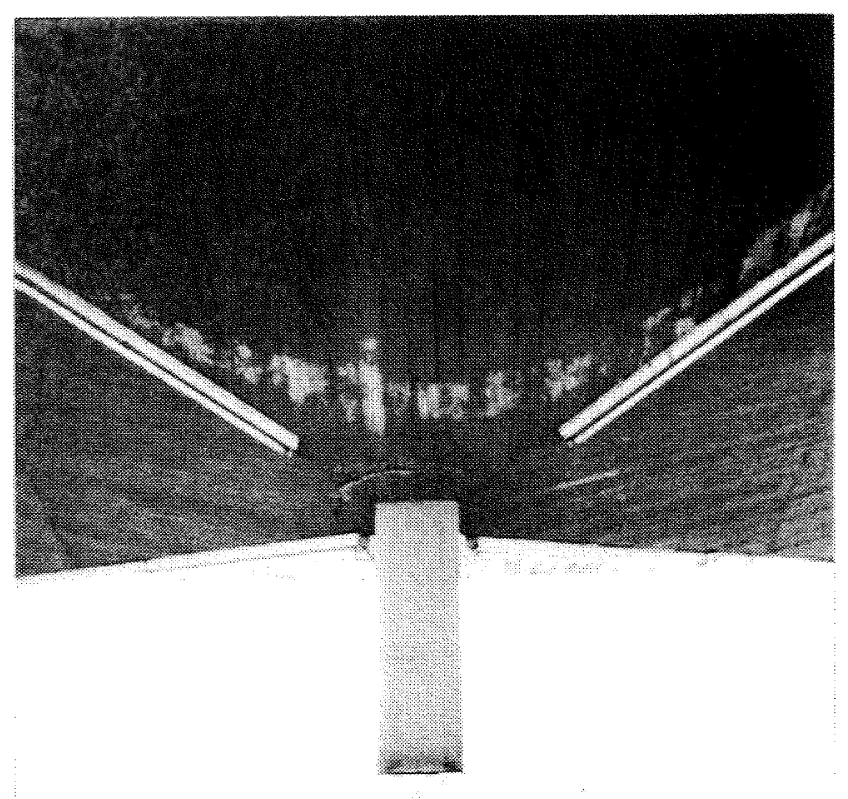

FIGURE 24: CRACKING IN ROOF OF SERVICE STATION SHELTER.

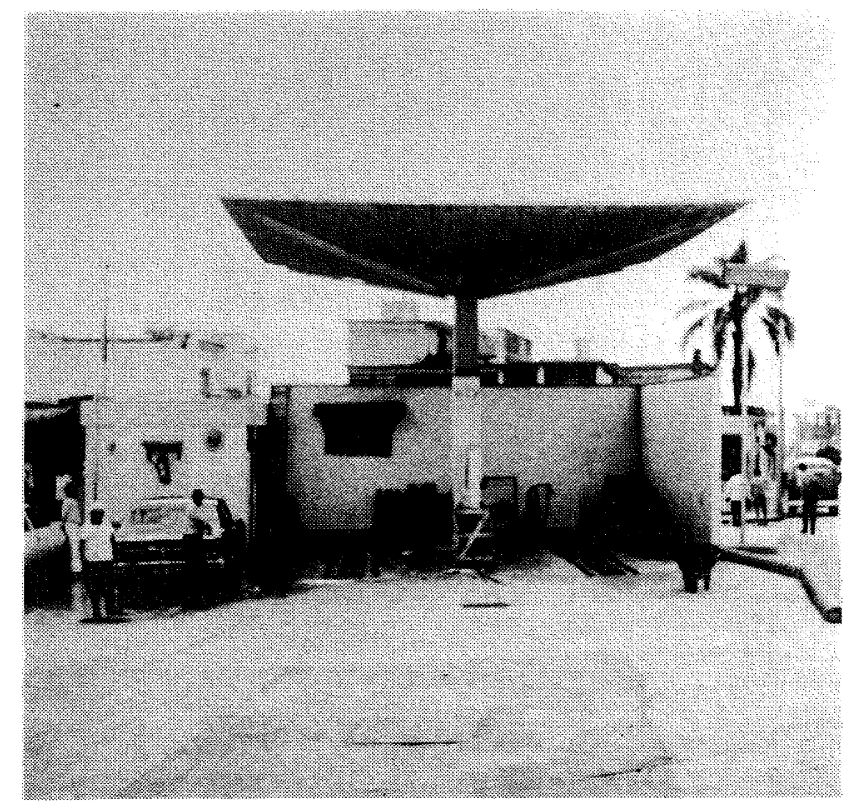

FIGURE 23: SERVICE STATION SHELTER, CORDOBA.

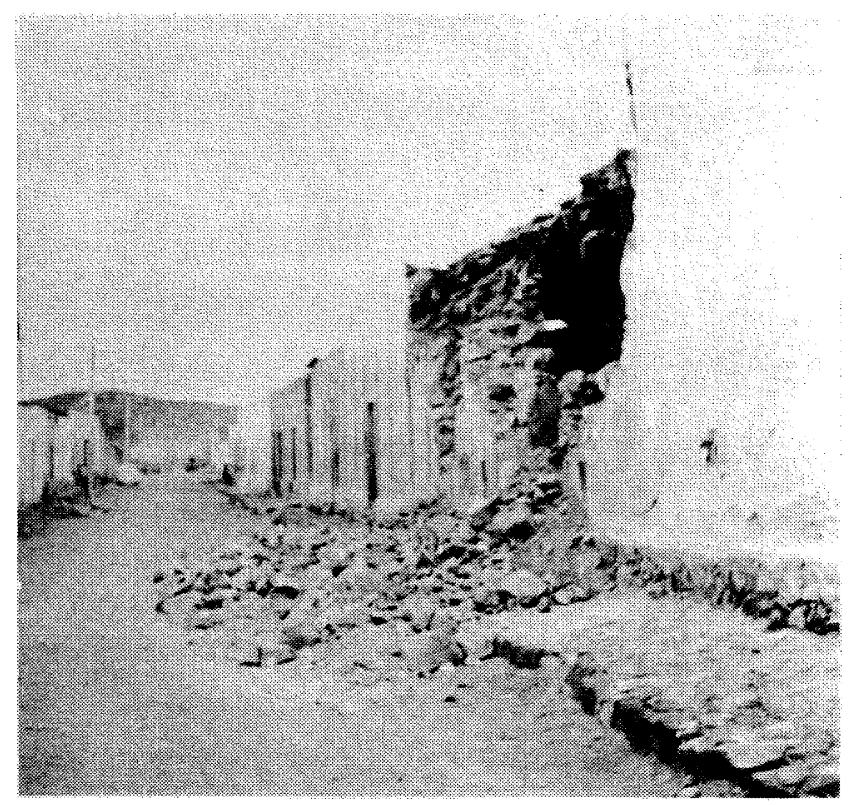

FIGURE 25: TYPICAL VIEW OF DAMAGE TO HOUSING IN SERDAN. 